\title{
Zerumbone from Zingiber zerumbet (L.) smith: a potential prophylactic and therapeutic agent against the cariogenic bacterium Streptococcus mutans
}

Thiago Moreira da Silva', Carlos Danniel Pinheiro' ${ }^{1}$ Patricia Puccinelli Orlandi², Carlos Cleomir Pinheiro' and Gemilson Soares Pontes ${ }^{3^{*}}$ (D)

\begin{abstract}
Background: Essential oil obtained from rhizomes of the Zingiber zerumbet (L.) Smith (popularly known in Brazil as bitter ginger) is mainly constituted by the biomolecule zerumbone, which exhibit untapped antimicrobial potential. The aim of this study was to investigate the antimicrobial activity of the zerumbone from bitter ginger rhizomes against the cariogenic agent Streptococcus mutans.

Methods: Firstly, the essential oil from rhizomes of Zingiber zerumbet (L.) Smith extracted by hydrodistillation was submitted to purification and recrystallization process to obtain the zerumbone compound. The purity of zerumbone was determined through high-performance liquid chromatography analysis. Different concentrations of zerumbone were tested against the standard strain S. mutans (ATCC 35668) by using microdilution method. The speed of cidal activity was determined through a time kill-curve assay. The biological cytotoxicity activity of zerumbone was assessed using Vero cell line through MTT assay.

Results: The zerumbone showed a minimum inhibitory concentration (MIC) of $250 \mu \mathrm{g} / \mathrm{mL}$ and a minimum bactericidal concentration (MBC) of $500 \mu \mathrm{g} / \mathrm{mL}$ against S. mutans. After six hours of bacteria-zerumbone interaction, all concentrations tested starts to kill the bacteria and all bacteria were killed between 48 and $72 \mathrm{~h}$ period at the concentration of $500 \mathrm{\mu g} / \mathrm{mL}$ (99,99\% of bacteria were killed in comparison with original inoculum). In addition, zerumbone showed no cytotoxicity activity on mammalian continuous cells line.

Conclusions: These results draw attention to the potential of zerumbone as antimicrobial agent against S. mutans infection, indicating its possible use in the phyto-pharmaceutical formulations as new approach to prevent and treat tooth decay disease.
\end{abstract}

Keywords: Tooth decay, Zerumbone, Bioprospecting, Antimicrobial, Treatment, Phytotherapy

\section{Background}

Several medicinal plants contain in their biochemical constitution many compounds with antibacterial action, that remains unknown [1]. Zingiber zerumbet (L.) Smith, a rhizomatous herbaceous species, belonging to the

* Correspondence: pontesbm1@gmail.com

${ }^{3}$ Instituto Nacional de Pesquisa da Amazônia, Coordenação Sociedade,

Ambiente e Saúde, Av. André Araújo - 2936 - Petrópolis, Manaus 69067-375,

Amazonas, Brazil

Full list of author information is available at the end of the article family Zingiberaceae, is a native plant from Southeast Asia with potential antimicrobial activity not fully comprehended [2]. In Brazil, this species is usually identified as bitter ginger and is easily found in large numbers in the Amazonas state, where it is well adapted to the local climatic conditions.

Essential oils extracted from Zingiber zerumbet rhizomes have potential pharmacological activities, including antimicrobial, anti-inflammatory, chemo-preventive, antinociceptive, antiulcer, antioxidant, antipyretic and analgesic, as previously described [3-7]. The major

(c) The Author(s). 2018 Open Access This article is distributed under the terms of the Creative Commons Attribution 4.0 International License (http://creativecommons.org/licenses/by/4.0/), which permits unrestricted use, distribution, and 
bioactive molecule found in the essential oil of Zingiber zerumbet rhizomes is the zerumbone (Fig. 1), a monocyclic sesquiterpene compound (2,6,10-cy-cloundecatrien-1-one, 2,6,9,9-tetramethyl-,(E,E,E)-) [8]. Zerumbone has been linked to a broad range of biological activities, including the antibacterial action $[9,10]$.

Previous reports have demonstrated the antimicrobial activities of zerumbone against Gram negative bacteria, such as Escherichia coli and Helicobacter pylori, and Gram positive bacteria, such as Staphylococcus epidermidis and Staphylococcus aureus, showing more effectiveness on Gram positive microorganisms [7, 11]. However, its activity against other Gram positive microorganisms such as Streptococcus mutans is unknown. S. mutans is the main causative agent of tooth decay, the oral infectious disease most prevalent in the world affecting over $90 \%$ of school-aged children and about $100 \%$ of the world population [12].

Despite the great diversity of bacterial species in the oral cavity, few are able to cause tooth decay (cariogenic bacteria) and $S$. mutans has been implicated as the major etiological agent of this oral infectious disease [13]. The cariogenic potential displayed by this bacterium is due to its ability to produce acid (acidogenic) from dietary carbohydrate, capacity to survive in low-pH environments (aciduric) and, especially, due to its great ability to adhere onto the tooth surfaces, which makes $S$. mutans responsible for the initial formation of dental plaque [14].

Chemicals agents such as chlorexidin and others phenolic compounds are available and can be used to prevent

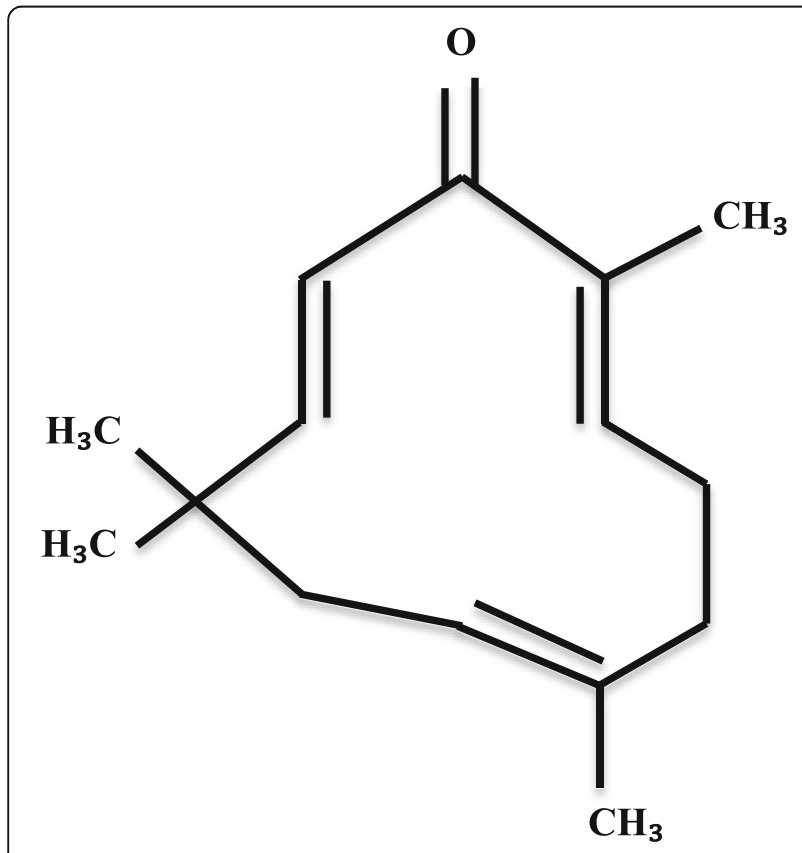

Fig. 1 Chemical structure of zerumbone tooth decay, but long term use of these compounds may result in side effects like loss of taste, metallic taste in mouth, dental pigmentation, diarrhea and oral burning sensation [15]. In this context, biomolecules isolated from plants have been suggested as alternative therapeutics over synthetic chemical agents for prevention of tooth decay, because of their few or no side effects [16]. Hence, the main goal of this study was to investigate the antimicrobial activity of the zerumbone obtained from rhizomes of Zingiber zerumbet (L.) Smith against $S$. mutans, the main etiological agent of tooth decay.

\section{Methods}

\section{Acquisition of Zingiber zerumbet rhizomes}

The rizhomes of the $Z$. zerumbet were collected in a rural area surrounding the city of Manaus/AM, located at BR-174, points P01 to P02, latitude 24132, $03789 \mathrm{~S}$ and longitude 600931,40854 W, according to geographic coordination. After that, an exsiccate was sent to the herbarium of the National Institute of Amazonian Research (INPA) for proper identification and comparison with the exsiccate previously identified by Prof. Dr. Paul Maas (Department of Plant Ecology and Evolutionary Biology; Herbarium University of Utrecht), which is deposited in the herbarium under $\mathrm{N}^{\circ} .186913$.

\section{Essential oil extraction}

The extraction of the essential oil (EO) was carried out in the Thematic Laboratory of Chemistry and Natural Products at INPA. The EO was obtained through the hydrodistillation of rhizomes. Briefly, after the identification, cleaning and disinfection, the material was crushed and dried at room temperature. Clevenger apparatus adapted with a round-bottom flask of 21 volume was used for distillation of $\mathrm{OE}$ from the crushed material diluted in distilled water in a proportion 1:4. The extraction was done during $6 \mathrm{~h}$ starting at boiling point. Afterward, the EO was collected from the condenser and stored in amber flasks at room temperature. All system was protected from light using aluminum foil. The $\mathrm{OE}$ yield was estimated by calculating the ratio between the oil mass and the feed mass.

\section{Gas chromatography-mass spectrometry (GC-MS) analysis}

The GC-MS analysis was performed as previously described, with few modifications [17]. Briefly, the investigation of essential oil composition was carried out using Hewlett Packard HP/série 6890 GC SITEM PLUS gas chromatographer (6511 Bunker Lake Blvd. Ramsey, Minnesota, 55303 USA) with an analytical HP-5MS 5\% phenylmethylsiloxane capillary column $(30 \mathrm{~m} \times 0.32 \mathrm{~mm}$ i.d, film thickness $0,25 \mu \mathrm{m})$. It was operated an electron ionization system with ionization energy of $70 \mathrm{~V}$. The 
analyses were conducted using helium and nitrogen gases at $2 \mathrm{~mL} / \mathrm{min}$ with purity percentage of $99.999 \%$. It was injected $1 \mu \mathrm{L}$ in splitless mode, in 1:20 ratio of hexannic solution. The oven was programmed at controlled temperature between 60 and $240{ }^{\circ} \mathrm{C}$, raising $3{ }^{\circ} \mathrm{C} / \mathrm{min}$ and kept at $250{ }^{\circ} \mathrm{C}$ for $10 \mathrm{~min}$. Temperature of mass transfer and injection were established at $220{ }^{\circ} \mathrm{C}$ and $290{ }^{\circ} \mathrm{C}$, respectively. The chemical constituents of essential oil analyzed were expressed as relative percentage by peak area normalization. The identification of the $\mathrm{OE}$ constituents was done by calculating the retention time obtained in the analyzes of GC-MS, correlating them with the retention times of the $n$-alkanes $(\mathrm{C} 9-\mathrm{C} 30)$. The indices were compared with the data available in the NIST / WILEY library [18]. The zerumbone identification was done as previously described [19].

\section{High-performance liquid chromatography (HPLC)}

After purification and recrystallization of the EO using our patented method ( ${ }^{0}$ PI-0505343-9/28/11/2007), the zerumbone purity was estimated through HPLC analysis (Accela High Speed LC, Thermo Scientific ${ }^{\circ}$ ), using a column Hypersil Gold $(50 \times 2,1 \mathrm{~mm})$ and a mobile phase methanol:water $(85: 15, v / \mathrm{v})$ at $1 \mathrm{~mL} / \mathrm{min}$. The identification was done by comparing the retention time of the peaks with those standard solutes in HPLC and confirmed by UV-absorption spectrum $(\sim 252 \mathrm{~nm})$.

\section{Inoculum standardization}

The antimicrobial activity of the zerumbone was evaluated against the standard strain of $S$. mutans ATCC 35668 (American Type Culture Collection, Microbiologics Inc., St. Cloud, USA) [20]. Firstly, bacterial suspensions were prepared by inoculation of colonies into a tube containing $3 \mathrm{~mL}$ Brain Heart Infusion (BHI) broth, followed by incubation at orbital shaking of $150 \mathrm{RPM}$ for $72 \mathrm{~h}$ at $37{ }^{\circ} \mathrm{C}$ in anaerobic conditions, as previously described [21] . After incubation, the turbidity was calibrated and adjusted through spectrophotometer analysis to match the 0,5 MacFarland scale $\left(1 \times 10^{8} \mathrm{CFU} / \mathrm{mL}\right)$. Final inoculum of $1 \times 10^{6} \mathrm{CFU} / \mathrm{mL}$ was used in the assays.

\section{Determination of the antimicrobial activity}

The antimicrobial activity of zerumbone was evaluated by estimation of Minimum Inhibitory Concentration (MIC) and Minimum Bactericidal Concentration (MBC) using microdilution method according to the guidelines of the Clinical \& Laboratory Standards Institute (CLSI) [22]. The working stock solution of zerumbone was prepared in polyethylene glycol sorbitan monolaurate (Tween 20) under vigorous magnetic stirring system to assure homogeneity, as previously described [7]. After diluting serially this working stock solution in 96 well-plate containing $100 \mu \mathrm{L}$ BHI broth, $100 \mu \mathrm{L}$ of BHI broth having bacterial inoculum $\left(1 \times 10^{6} \mathrm{CFU} / \mathrm{mL}\right)$ were added into wells resulting in a final volume of $200 \mu \mathrm{L}$, followed by incubation at the same conditions mentioned above. The concentrations of zerumbone tested ranged from 125 to $2000 \mu \mathrm{g} / \mathrm{mL}$. Additional wells containing diluting agent of zerumbone (tween 20 10\%) was used as a control.

After incubation, the bacterial growth was evaluated by measuring the turbidity in each well through spectrophotometric analysis $(600 \mathrm{~nm})$. Subsequently, an aliquot of $50 \mu \mathrm{L}$ of each well was collected and seeded on plates containing BHI agar and incubated for $72 \mathrm{~h}$ at $37^{\circ} \mathrm{C}$ in anaerobic conditions. Next, the plates were analyzed for the presence/absence of bacteria in order to estimate the MIC and MBC. The MIC was estimated according to lowest concentration of zerumbone that inhibits the bacterial growth. The MBC was assessed based on the concentration that kills all viable bacterial cells and therefore reveals no visible bacterial growth on the plates. The number of surviving cells $(\mathrm{CFU} / \mathrm{mL})$ was determined through the direct-plate counting technique performed individually by two skilled technicians. The limit of detection used in all tests was 10 CFU. An estimated count was provided in case of countable colonies were presented below this limit, as previous reported [23]. All tests were done in triplicate and repeated three times to verify the reproducibility of results.

\section{Time-kill curve assay}

To determine the speed of cidal activity of the zerumbone, a time kill-curve was performed as previously described, with few modifications [24] . An inoculum of $1 \times 10^{6} \mathrm{CFU} / \mathrm{mL}$ was added into tubes having $3 \mathrm{~mL}$ of BHI broth or BHI broth treated with zerumbone (MIC or MBC values) or tween $2010 \%$ (control) and then incubated for $72 \mathrm{~h}$ anaerobically with orbital rotation of $150 \mathrm{RPM}$ at $37{ }^{\circ} \mathrm{C}$. The tube containing only bacteria and $\mathrm{BHI}$ broth was used to estimate the different phases of growth curve.

An aliquot of $100 \mu \mathrm{L}$ was removed at $0,6,12,24,48$ and $72 \mathrm{~h}$ time intervals to determine the bacterial growth by measuring turbidity through spectrophotometric analysis $(600 \mathrm{~nm})$. Subsequently, the aliquots were serially diluted in $0.85 \%$ of sterile saline solution, seeded in BHI agar and then incubated at the conditions set out above. The viable number of bacterial cells was estimated by counting CFU and multiplying the results by dilution factors. Means of duplicate colony counts were taken. To build the time-kill curve, the $\log _{10}$ CFU/ $\mathrm{mL}$ versus time over $72 \mathrm{~h}$ was plotted. The decrease of 99.9\% ( $\geq 3 \log _{10}$ ) of the total number of $\mathrm{CFU} / \mathrm{mL}$ in the original inoculum was used to estimate the bactericidal activity. The assays were performed in triplicate and 
repeated three times to confirm the reproducibility of results.

\section{Cytotoxicity assay}

The cytotoxicity activity of zerumbone was determined using the MTT (3-(4, 5-dimethyl thiazol-2-yl)-2, 5-diphenyl tetrazolium bromide) assay as previously described with few modifications [21]. Summarily, Vero cells line $\left(2 \times 10^{4}\right.$ per well) were cultured into 96-well plate containing $0.2 \mathrm{~mL}$ of DMEM medium (with $10 \%$ FBS, penicillin-streptomycin and amphotericin B) per well, in atmosphere of $5 \% \mathrm{CO}_{2}$ at $37{ }^{\circ} \mathrm{C}$ for $24 \mathrm{~h}$. After formation of sub-confluent monolayer, the cells were treated with zerumbone $(25 \mu \mathrm{g} / \mathrm{mL} ; 50 \mu \mathrm{g} / \mathrm{mL}$ and $100 \mu \mathrm{g} / \mathrm{mL}$ ) and incubated again at the same conditions above mentioned for 24 and $48 \mathrm{~h}$. For this assay, crystals of zerumbone were diluted in 100\% dimethyl sulfoxide (DMSO) because of its low aqueous solubility. Thus, the maximum concentration of zerumbone containing safe percentage of DMSO $(<1 \%)$ to the cells was $100 \mu \mathrm{g} / \mathrm{mL}$. Sterile PBS was used as positive control and DMSO $100 \%$ as negative control. Subsequently, the medium was removed from all wells and $10 \mu \mathrm{L}$ of MTT $(5 \mathrm{mg} / \mathrm{mL}$ in sterile PBS) diluted in $100 \mu \mathrm{L}$ of DMEM medium (without phenol red to avoid misinterpretation) was added into the wells and incubated in atmosphere of $5 \% \mathrm{CO}_{2}$ at $37{ }^{\circ} \mathrm{C}$ for $4 \mathrm{~h}$. After that, the MTT was removed and $50 \mu \mathrm{L}$ of MTT lysis buffer were added to each well followed for gently homogenization to dissolve the formazan crystals and incubated again for $10 \mathrm{~min}$ at the same conditions mentioned earlier. Optical densities of samples were measured using a microplate reader at wavelength of $570 \mathrm{~nm}$. The relative viability of cells was estimated using the following equation: (A570 of treated sample $) /($ A570 of untreated sample $) \times 100$. All tests were done in triplicate.

\section{Statistical analyses}

Descriptive statistics was used to summarized and describe de data. The results are expressed in mean \pm SD.

\section{Results}

Acquisition of Essential oil and purification of zerumbone The yield of the essential oil obtained was $5 \%$. The EO showed to be constituted mainly by sesquiterpene zerumbone compound, according to GC-MS analysis (Fig. 2). A percentage of $87,93 \%$ of zerumbone was detected among the nineteen others chemical constituents. The purification and recrystallization processes applied to EO resulted in a zerumbone crystal with $98 \%$ of purity (Fig. 3). These crystals were used in all subsequent tests.

\section{Antimicrobial activity of zerumbone}

The zerumbone substance tested in this study demonstrated antimicrobial activity against $S$. mutans ATCC 35668, showing a MIC value of $250 \mu \mathrm{g} / \mathrm{mL}$ and MBC of $500 \mu \mathrm{g} / \mathrm{mL}$ (Fig. 4, Additional file 1: Figure S1). The time-kill curve assay corroborates the antimicrobial activity of zerumbone. This biomolecule displayed more

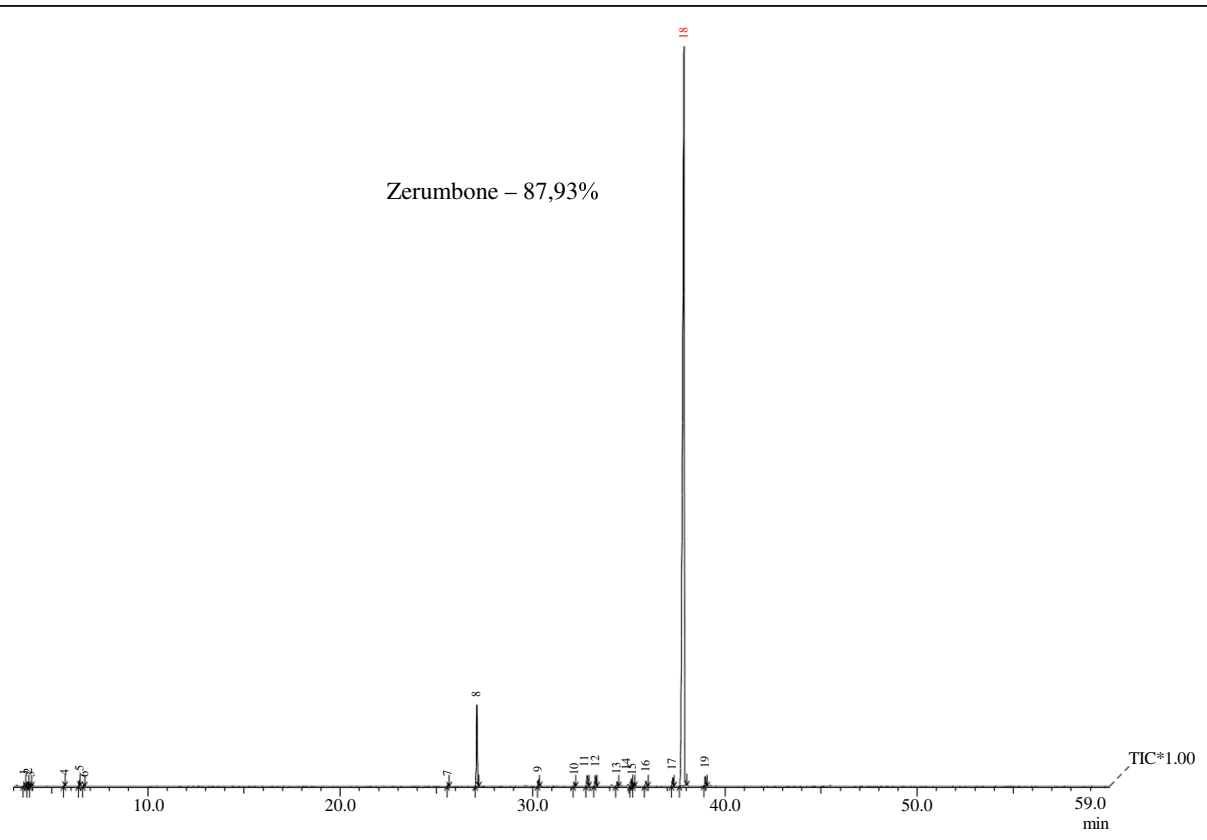

Fig. 2 Gas Chromatography-Mass Spectrometry (GC-MS) of Essential oil Zingiber zerumbet (L.) Smith. Analysis revealed the presence of 19 compounds. Zerumbone was the major compound (87,93\%) found in the essential oil used in this study.* R. time: retention time 


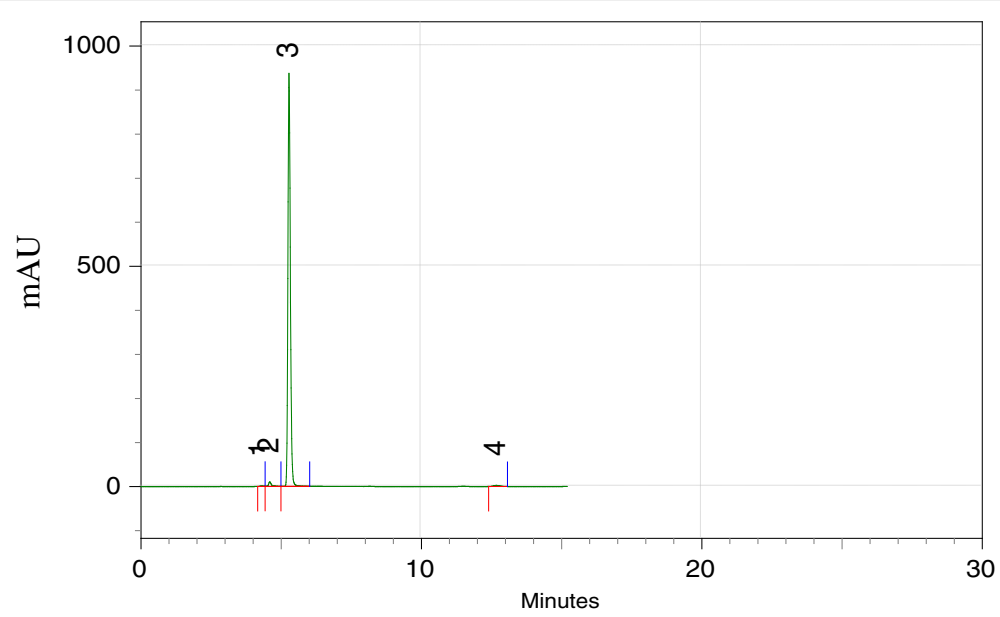

Fig. 3 High-performance liquid Chromatography (HPLC) of zerumbone crystals. HLPC elution of zerumbone crystal with retention time of $\sim 5$ min confirmed zerumbone purity of $98 \%$ (peak 3)

intense antibacterial activity in the time interval $12-$ $48 \mathrm{~h}$, corresponding to log phase of $S$. mutans growth curve (Additional file 2: Figure S2). Within $12 \mathrm{~h}$ of bacterial exposure to $250 \mu \mathrm{g} / \mathrm{mL}$ and $500 \mu \mathrm{g} / \mathrm{mL}$ of zerumbone concentrations, viable bacterial cells were reduced in $45.55 \%$ and $56,29 \%$, respectively, in comparison to the original inoculum (Fig. 4a). After $24 \mathrm{~h}$ of exposure, the reduction was more pronounced with $65.46 \%(250 \mu \mathrm{g} /$ $\mathrm{mL})$ and $70.62 \%(500 \mu \mathrm{g} / \mathrm{mL})$ of bacterial cells death (Fig. $4 \mathrm{~b}$ and c). Finally, the zerumbone showed its

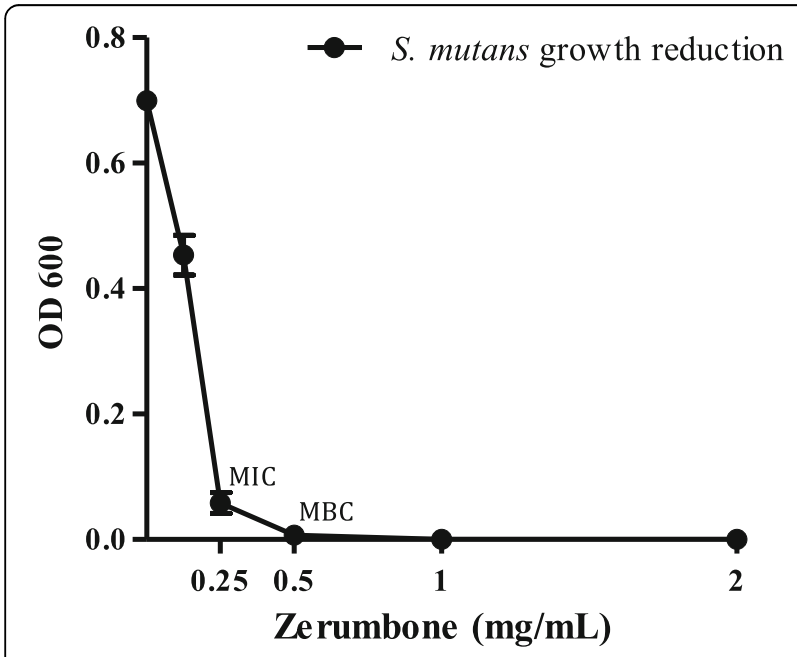

Fig. 4 Antimicrobial activity (MIC and MBC) of zerumbone against $S$. mutans. Bacterial inoculum $\left(1 \times 10^{6} \mathrm{CFU} / \mathrm{mL}\right)$ was treated with different concentrations of zerumbone and incubated at $37^{\circ} \mathrm{C}$ for $48 \mathrm{~h}$ in anaerobic conditions. After incubation, the bacterial growth was verified by turbidity measurements using spectrophotometer. The results are representative of three independent experiments performed in triplicate and the values are shown in mean \pm SD. OD: optical density; MIC: Minimum Inhibitory Concentration; MBC: Minimum bactericidal concentration maximum action in the interval of $48-72 \mathrm{~h}$, reducing $94.78 \%$ of bacterial colonies at concentration of $250 \mu \mathrm{g} /$ $\mathrm{mL}$ and killing all bacteria at the concentration of $500 \mu \mathrm{g} / \mathrm{mL}$ (Fig. 5a, b and c).

\section{Cytotoxicity activity of zerumbone}

The MMT assay demonstrated that the biomolecule zerumbone had no considerable cytotoxicity effect up to $100 \mu \mathrm{g} / \mathrm{mL}$. At concentrations 25,50 and $100 \mu \mathrm{g} / \mathrm{mL}$ the percentages of cell viability were 100, 97 and $92 \%$, respectively, after $24 \mathrm{~h}$ treatment (Fig. 6). The cell viability slightly changed at concentration $50 \mu \mathrm{g} / \mathrm{mL}(93 \%)$ and $100 \mu \mathrm{g} / \mathrm{mL}(87 \%)$ after $48 \mathrm{~h}$ treatment. The results clearly show that the zerumbone has no cytotoxic effect on normal mammalian cells at the concentrations tested.

\section{Discussion}

Tooth decay disease is a growing global concern that is known to threaten human health and safety [25]. Emerging antibiotic resistance and inconvenient side effects caused by commercial antibiotics usually result in leaving treatment [26]. In this regard, the development of alternative antibiotic therapies based on bioactive molecules from medicinal plants is urgent and crucial to provide effective prevention and treatment for tooth infection.

The present study demonstrates strong antimicrobial activity of zerumbone against the cariogenic agent $S$. mutans (MIC $=250 \mu \mathrm{g} / \mathrm{mL}$ ). according to the following classification of antimicrobial action: strong $=50<\mathrm{MIC}<$ $500 \mu \mathrm{g} / \mathrm{mL}$ moderate $=$ MIC $600<$ MIC $<1500 \mu \mathrm{g} / \mathrm{mL}$ and; weak $=\mathrm{MIC}>1500 \mu \mathrm{g} / \mathrm{mL}[27,28]$. Our data therefore brings to light a new possibility of prophylactic and therapeutic strategies for $S$. mutans infection, especially in case of tooth decay, a serious public health issue [29]. 

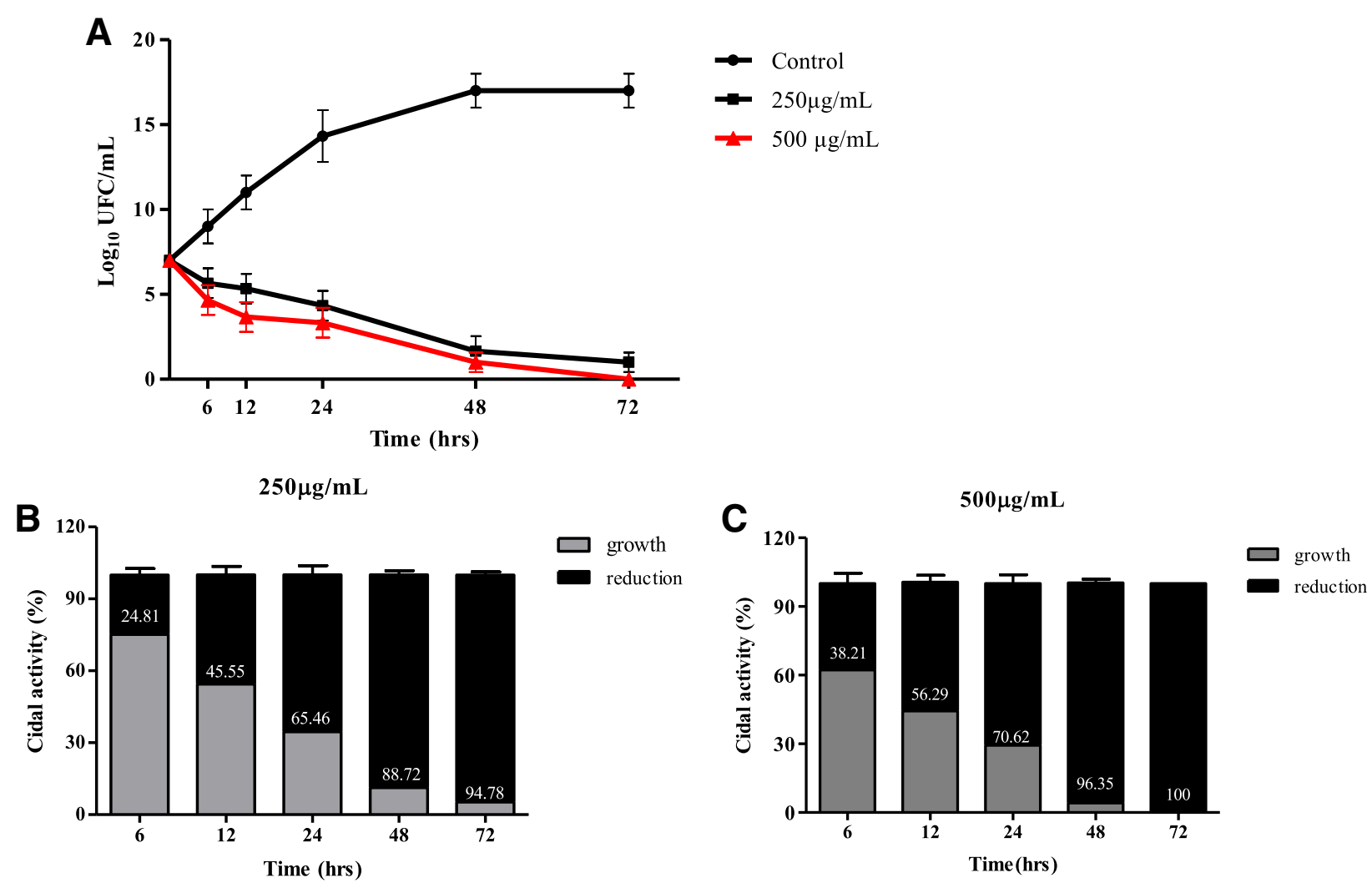

Fig. 5 Bacterial- time kill curve. Zerumbone was tested for antimicrobial activity on bacterial-kill kinetics. S. mutans were grown in BHI broth + tween $2010 \%$ (control) or along with graded concentrations of zerumbone at $37^{\circ} \mathrm{C}$ for $72 \mathrm{~h}$ in anaerobic conditions. Samples were collected at different time intervals to estimate bacterial kill kinetics (a) and growth reduction (b and $\mathbf{c}$ ), by spectrophotometry analysis and CFU counts. Numbers inside of bars at (b) and (c) figures means percent reduction. Results are representative of three independent experiments and data are expressed in mean $\pm \mathrm{SD}$. The interquartile range of each data is indicated by error bars

Few reports have been found related to antimicrobial activity of natural biomolecules against the S. mutans earlier, but majority demonstrated weak antibacterial action based on the classification set out above [30-32]. A recent study tested around two thousand plant extracts from Amazon region, with seventeen extracts displaying antimicrobial activity against $S$. mutans (ATCC 25175). However, of these, only one extract obtained from plant Ipomoea alba L. sp. (Convolvulaceae) had strong $(\mathrm{MBC} \geq 160 \mu \mathrm{g} / \mathrm{mL})$ antimicrobial activity

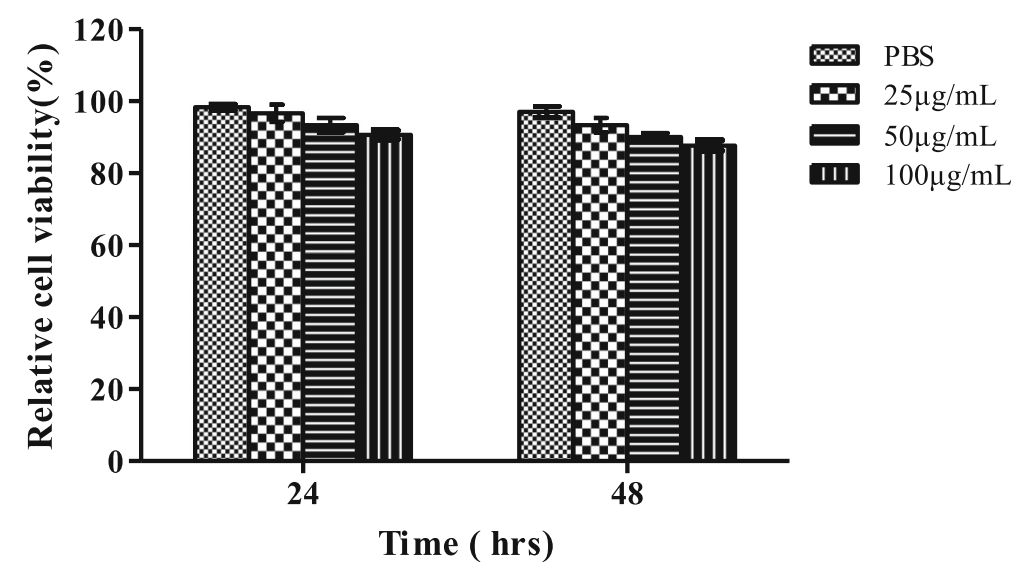

Fig. 6 Cytotoxicity of zerumbone against Vero cell line using MTT assay. The data are representative of three independent experiments and the results are expressed in mean $\pm S D$ 
[33]. Takarada et al. [34] and Aguiar et al. [35] evaluated the anti-S. mutans activity of essential oils from the following plants: Romarinus officinalis L., Melaleuca alternifólia, Lavandula officinalis, Leptosperfum scoparium, Eucalyptus radiate, Ageratum conyzoides, Artemisia camphorata Vill., Bidens sulphurea, Foeniculum vulgare Mill., Lippia alba, Ocimum gratissimum L., Pelargonium graveolens, Syzygium aromaticum and Tagetes erecta L. The results showed MICs ranging from 500 to $10,000 \mu \mathrm{g} / \mathrm{mL}$, antimicrobial activities considered weak as compared to our data. Therefore, these studies corroborate the strong bioactive potential of the zerumbone as anticariogenic agent, which could be a good substrate to be used in prophylactic and therapeutic formulations against tooth decay.

Indeed, zerumbone has been tested against a wide range of microorganisms and have showed good antibacterial activity, mainly against gram positive bacteria [36]. But, until now, there is no report describing the antimicrobial activity of the zerumbone or its analogs against $S$. mutans. Hasan et al. [37] demonstrated that extracts from Zingiber officinale, species that belongs to same genus and family of bitter ginger, has anti-S. mutans action with MIC value of $256 \mu \mathrm{g} / \mathrm{mL}$, effect similar to the one observed in this study. However, unlike our study, no compound was isolated or purified to determine which biomolecules were responsible for the observed antimicrobial activity. Generally, the essential oil obtained from Zingiber zerumbet shows in its constitution a range of zerumbone concentration starting from 12 to $73 \%$ [8]. Nevertheless, the essential oil obtained in our study showed $87,93 \%$ of zerumbone, which was raised to $98 \%$ after purification and recrystallization process using a method patented by our group $\left(\mathrm{n}^{0}\right.$ PI-0505343-9/28/11/2007). This degree of purity is greater than the ones described elsewhere, which allow us to better characterize the zerumbone antimicrobial action [9].

Since zerumbone exhibited efficient antimicrobial activity, we next evaluated the speed of cidal activity. The effectiveness observed was concentration and time-dependent, although both concentrations tested showed similar results. The intensity of zerumbone antimicrobial activity was pronounced during the logarithmic growth phase. After $24 \mathrm{~h}$ of bacterial exposure to 250 and $500 \mu \mathrm{g} / \mathrm{mL}$ zerumbone concentrations, viable bacterial cells were reduced to 65.46 and $70.62 \%$, respectively. According to Jones et al. [38] when an antimicrobial agent reduces the bacterial colonies around $70 \%$ within $24 \mathrm{~h}$ time period, it can be considered as a strong candidate for treating bacterial infections. However, the maximum cidal activity of zerumbone was reached at stationary phase, suggesting the possibility of two mechanism of zerumbone activity, different from the most antibiotic agents that require cell division or active metabolism for the drug's killing activity [39, 40]. Thus, an antibiotic agent that still shows bactericidal activity under growth-limited conditions may be very advantageous, since the biofilm-associated microorganisms, such as $S$. mutans, may modulate gene expression to enhance endurance under periods of nutrient limitation to survive in the stationary phase [41]. However, further studies are needed to elucidate the antibacterial mechanism of action of zerumbone.

Beyond the determination of the optimum antibacterial concentration, it is also important to guarantee the cytotoxicity safety of the bioactive substances against normal mammalian cells, if the ultimate goal is to use it as a main raw material to produce new drugs. Usually, finding the balance between effectiveness and safety of a biomolecule is very hard mission [42, 43]. Our findings indicated that the zerumbone may not be cytotoxic to normal mammalian cells, since the exposure of Vero cells to different concentrations of zerumbone cause no considerable toxic effects at the concentrations tested. Even after $48 \mathrm{~h}$ of zerumbone treatment, no substantial toxic effect was observed, other than a low cytotoxicity evidenced at $100 \mu \mathrm{g} / \mathrm{mL}$ concentration (reduction of $13 \%$ of cell proliferation). However, it is imperative to consider that the susceptibility of mammalian cells tend to be greater in the MTT test than in vivo situation, because of the direct exposure of the cells to the biomolecules without any type of variants happening in vivo, such as route of administration and topical absorption, which may influence or even though decrease the cytotoxicity effect demonstrated in vitro [44]. On the other hand, it is important to mention that additional experiments are needed to ensure safe use of zerumbone for humans.

Altogether, this study demonstrates the antimicrobial activity of zerumbone against $S$. mutans, showing that its toxic activity selectively targets bacterium, but not displays any cytotoxic effect against the normal mammalian cells at concentrations tested. Nonetheless, further studies using in vitro and in vivo models are needed to better determine the zerumbone effectiveness and safety as antimicrobial agent in the context of prophylaxis and treatment of cariogenic infections.

\section{Conclusions}

In summary, this study suggests that zerumbone represents a bioactive substance to be explored by phytopharmaceutical industry in the drug formulations, to prevent and treat cariogenic infections, because this biomolecule showed antimicrobial activity against the main etiological agent of tooth decay, S. mutans. Although the cytotoxicity safety of zerumbone in mammalian cells (at 
concentrations tested) and its antibacterial action at both $\log$ and stationary phases support its potential use as antibacterial agent against $S$. mutans infection, additional studies are necessary to better characterize the zerumbone mechanism of action, efficacy and safety in the scenario of cariogenic disease.

\section{Additional files}

Additional file 1: Figure S1. Agar $\mathrm{BH}$ showing presence or absence of S. mutans CFU representing the MIC and MIB of zerumbone against $S$. mutans. Results are representative of three independent experiments performed in triplicate. Arrows: CFU. (PPTX $454 \mathrm{~kb}$ )

Additional file 2: Figure S2. Bacterial growth curve of S. mutans cells grown in $\mathrm{BHI}$ broth for $48 \mathrm{~h}$ at 37 in atmosphere of $5 \% \mathrm{CO}_{2}$ at $37^{\circ} \mathrm{C}$. (PPTX $43 \mathrm{~kb}$ )

\section{Abbreviations}

BHI: Brain heart infusion; CFU: Colony forming units; DMSO: Dimethyl sulfoxide; MBC: Mininum bactericidal concentration; MIC: Minimum inhibitory concentration; OD: optical density; RPM: Rotation per minute

\section{Acknowledgements}

We would like to express our sincere gratitude to the Thematic laboratory of Chemistry and Natural Products of National Institute of Amazonian Research to all support provided through the execution of this research.

\section{Funding}

This research was financially supported by Projects Financing Institution (FINEP) of Brazilian Innovation Agency (grant number 01140113.030071/13). The funder had no role in the design of this study, data collection and analysis, and in writing the manuscript.

\section{Availability of data and materials}

The dataset of the present study may be available from the corresponding author upon request.

\section{Authors' contributions}

TMS, PPO and GSP performed study design, carried out antimicrobial and cell culture experiments, analyzed and interpreted the data, and drafted and revised the manuscript. CCP and CDP performed GC-MS and HPLC analysis. GSP coordinated and supervised the study. All authors read and approved the final manuscript.

\section{Author's information}

TM Silva is a Master degree student at Amazonas State University. CD Pinheiro is master in Biotechnology. PP Orlandi is PhD in Science and associate researcher at Maria Deane institute-Fiocruz. CC Pinheiro is PhD in Chemistry and Titular Researcher at National Institute of Amazonian Research- INPA. GS Pontes is PhD in Medical Sciences and Associate Researcher at National Institute of Amazonian Research- INPA.

\section{Ethics approval and consent to participate}

Not applicable.

\section{Consent for publication}

All co-authors have consented for the publication of this manuscript.

\section{Competing interests}

The authors declare that they have no competing interests.

\section{Publisher's Note}

Springer Nature remains neutral with regard to jurisdictional claims in published maps and institutional affiliations.

\section{Author details}

'Instituto Nacional de Pesquisa da Amazônia, Coordenação de Tecnologia e Inovação, Av. André Araújo - 2936 - Petrópolis, Manaus, Amazonas 69067-375, Brazil. ${ }^{2}$ Instituto Leônidas e Maria Deane, Fundação Oswaldo Cruz, Rua Teresina, 476 - Adrianópolis, Manaus, AM 69057-070, Brazil. ${ }^{3}$ Instituto Nacional de Pesquisa da Amazônia, Coordenação Sociedade, Ambiente e Saúde, Av. André Araújo - 2936 - Petrópolis, Manaus 69067-375, Amazonas, Brazil.

Received: 11 August 2017 Accepted: 25 October 2018

Published online: 13 November 2018

\section{References}

1. Sadaka F. Nguimjeu C. Vroman I, Tighzert L, Couvercelle JP. Review on antimicrobial packaging containing essential oils and their active biomolecules. Innov. Food Sci. Emerg. Technol: Brachais CH; 2014

2. Zakaria ZA, Yob NJ, Jofrry SM, MMRMM A, Teh LK, Salleh MZ. Zingiber zerumbet (L.) Smith: A review of its ethnomedicinal, chemical, and pharmacological uses. Evidence-based Complement. Altern Med. 2011:2011:1-12

3. Fakurazi S, Hairuszah I, Mohd Lip J, Shanthi G, Nanthini U, Shamima AR, et al. Hepatoprotective action of zerumbone against paracetamol induced hepatotoxicity. J Med Sci. 2009;9:161-4.

4. Abdel Wahab SI, Abdul AB, Alzubairi AS, Mohamed Elhassan M, Mohan S. In vitro ultramorphological assessment of apoptosis induced by Zerumbone on (HeLa). J Biomed Biotechnol. 2009;2009.

5. Sulaiman MR, Tengku Mohamad TA, Shaik Mossadeq WM, Moin S, Yusof M, Mokhtar AF, et al. Antinociceptive activity of the essential oil of Zingiber zerumbet. Planta med. 2010;76:107-12. Available from: https://doi.org/10. 1055/s-0029-1185950.

6. Somchit MN. Zerumbone isolated from Zingiber zerumbet inhibits inflammation and pain in rats. J Med Plants Res. [Internet]. 2012;6:753-57. Available from: https://doi.org/10.5897/JMPR10.492.

7. Sidahmed HMA, Hashim NM, Abdulla MA, Ali HM, Mohan S, Abdelwahab SI, et al. Antisecretory, gastroprotective, antioxidant and anti-helicobcter pylori activity of zerumbone from Zingiber zerumbet (L.) smith. PLoS One. 2015; 10(3):1-20

8. Baby S, Dan M, Thaha ARM, Johnson AJ, Kurup R, Balakrishnapillaia P, et al. High content of zerumbone in volatile oils of Zingiber zerumbet from southern India and Malaysia. Flavour Fragr J. 2009;24:301-8. Available from: https://doi.org/10.1002/ffj.1940.

9. Rahman HS, Rasedee A, Yeap SK, Othman HH, Chartrand MS, Namvar F, et al. Biomedical properties of a natural dietary plant metabolite, Zerumbone, in cancer therapy and chemoprevention trials. Biomed Res Int. 2014;2014:1-20.

10. Adbul ABH, Al-Zubairi AS, Tailan ND, Wahab SIA, Zain ZNM, Rusley S, et al. Anticancer activity of natural compound (Zerumbone) extracted from Zingiber zerumbet in human HeLa cervical cancer cells. Int J Pharmacol. 2008:4:160-8.

11. Liu WY, Tzeng T-F, Liu I-M. Healing potential of zerumbone ointment on experimental full-thickness excision cutaneous wounds in rat. J. Tissue Viability, Elsevier Ltd. 2017. p. 6-11. Available from: https://doi.org/10.1016/j. jtv.2017.04.002.

12. Petersen PE. Strengthening of Oral health systems. Oral health through primary health care. Med Princ Pract. 2014;23:1-7. Available from: https:// doi.org/10.1159/000356937.

13. Bradshaw DJ, Lynch RJM. Diet and the microbial aetiology of dental caries: new paradigms. Int dent J. 2013;63(Suppl 2):64-72. Available from: https:// doi.org/10.1111/idj.12082.

14. Lynch DJ, Michalek SM, Zhu M, Drake D, Qian F, Banas JA. Cariogenicity of Streptococcus mutans glucan-binding protein deletion mutants. Oral Health Dent Manag. [Internet]. 2013;109:191-9. Available from: http://www.ncbi. nlm.nih.gov/pubmed/24525450.

15. Baehni PC, Takeuchi Y. Anti-plaque agents in the prevention of biofilmassociated oral diseases. Oral Dis. 2003;9(Suppl 1):23-9.

16. Palombo EA. Traditional Medicinal Plant Extracts and Natural Products with Activity against Oral Bacteria: Potential Application in the Prevention and Treatment of Oral Diseases. Evid Based Complement Alternat Med. [Internet]. 2011;2011:680354. Available from: https://doi.org/10.1093/ecam/nep067.

17. Gong HY, Liu WH, GY LV, Zhou X. Analysis of essential oils of Origanum vulgare from six production areas of China and Pakistan. Brazilian J Pharmacogn. 2014;24:25-32. 
18. Ben El Hadj Ali I, Chaouachi M, Bahri R, Chaieb I, Boussaïd M, Harzallah-Skhiri F. Chemical composition and antioxidant, antibacterial, allelopathic and insecticidal activities of essential oil of Thymus algeriensis Boiss. et Reut. Ind Crops Prod. 2015;77:631-9. Available from: https://doi.org/10.1016/j.indcrop. 2015.09.046.

19. Adams R. Identification of Essential Oil Components by Gas Chromatography / Mass Spectrometry. Identif. Essent. Oil Components by Gas Chromatogr. / Mass Spectrom. 1995;5.

20. TIB.2033, REV C. Conditions S. Microorganism Maintenance Plan for Laboratories Following ISO 11133. 2014;1-2.

21. Kumar SN, Lankalapalli RS, Kumar BSD. In vitro antibacterial screening of six proline-based cyclic dipeptides in combination with ??-lactam antibiotics against medically important bacteria. Appl Biochem Biotechnol. 2014;173: $116-28$.

22. CLSI. M45-A2 Methods for Antimicrobial Dilution and Disk Susceptibility Testing of Infrequently Isolated or Fastidious Bacteria ; Approved Guideline - 2nd edn. 2010

23. Sutton S. Accuracy of plate counts. J Valid Technol. 2011;17:42-6.

24. Sartoratto A, Machado ALM, Delarmelina C, Figueira GM, Duarte MCT, Rehder VLG. Composition and antimicrobial activity of essential oils from aromatic plants used in Brazil. Brazilian J Microbiol. 2004;35:275-80.

25. Friedman PK, Kaufman LB, Karpas SL. Oral health disparity in older adults. Dental decay and tooth loss. Dent Clin North Am. 2014;58(4):757-70.

26. Muts E-J, van Pelt H, Edelhoff D, Krejci I, Cune M. Tooth wear: a systematic review of treatment options. J Prosthet Dent. 2014;112:752-e9. Available from: https://doi.org/10.1016/j.prosdent.2014.01.018.

27. Webster D, Taschereau P, Belland RJ, Sand C, Rennie RP. Antifungal activity of medicinal plant extracts; preliminary screening studies. J Ethnopharmacol. 2008:140-6. Available from: https://doi.org/10.1016/j.jep.2007.09.014.

28. Bagramian RA, Garcia-Godoy F, Volpe AR. The global increase in dental caries. A pending public health crisis. Am. J. Dent. 2009;22:3-8.

29. Kassebaum NJ, Bernabe E, Dahiya M, Bhandari B, Murray CJ, Marcenes W. Global burden of untreated caries: a systematic review and metaregression. J Dent Res. 2015;94:650-8. Available from: https://doi.org/10.1177/ 0022034515573272.

30. Porto TS, Rangel R, Furtado NAJC, De Carvalho TC, Martins CHG, Veneziani RCS, et al. Pimarane-type diterpenes: antimicrobial activity against oral pathogens. Molecules. 2009;14:191-9.

31. Saleem M, Nazir M, Ali MS, Hussain H, Lee YS, Riaz N, et al. Antimicrobial natural products: an update on future antibiotic drug candidates. Nat Prod Rep [Internet]. 2010;27:238-54 Available from: https://doi.org/10.1039/ B916096E.

32. da Silva JPC, de Castilho AL, Saraceni CHC, Díaz IEC, Paciencia MLB, Suffredini IB. Anti-streptococcal activity of Brazilian Amazon rain Forest plant extracts presents potential for preventive strategies against dental caries. J Appl Oral Sci Rev FOB. 2014;22:91-7.

33. Freire ICM, P??rez ALAL, Cardoso AMR, Mariz BALA, Almeida LFD, Cavalcanti YW, et al. Atividade antibacteriana de ??leos essenciais sobre Streptococcus mutans e Staphylococcus aureus. Rev Bras Plantas Med 2014;16:372-377.

34. Takarada K, Kimizuka R, Takahashi N, Honma K, Okuda K, Kato T. A comparison of the antibacterial efficacies of essential oils against oral pathogens. Oral Microbiol Immunol. 2004;19:61-4.

35. Aguiar GP, Carvalho CE, Dias HJ, Reis EB, Martins MHG, Wakabayashi KAL, et al. Antimicrobial activity of selected essential oils against cariogenic bacteria. Nat Prod Res. 2013;27:1668-72. Available from: https://doi.org/10. 1080/14786419.2012.751595.

36. Santosh Kumar SC, Srinivas P, Negi PS, Bettadaiah BK. Antibacterial and antimutagenic activities of novel zerumbone analogues. Food Chem. 2013; 141:1097-103.

37. Hasan S, Danisuddin M, Khan AU. Inhibitory effect of Zingiber officinale towards Streptococcus mutans virulence and caries development: in vitro and in vivo studies. BMC Microbiol. 2015;15:1-14. Available from: https://doi. org/10.1186/s12866-014-0320-5.

38. Jones RN, Anderegg TR, Deshpande LM. AZD2563, a new oxazolidinone: bactericidal activity and synergy studies combined with gentamicin or vancomycin against staphylococci and streptococcal strains. Diagn Microbiol Infect Dis. 2002;43:87-90.

39. Anderl JN, Zahller J, Roe F, Stewart PS. Role of nutrient limitation and stationary-phase existence in Klebsiella pneumoniae biofilm resistance to ampicillin and ciprofloxacin. Antimicrob Agents Chemother. 2003;47:1251-6.
40. Gradelski E, Kolek B, Bonner D, Fung-Tomc J. Bactericidal mechanism of gatifloxacin compared with other quinolones. J Antimicrob Chemother. 2002;49:185-8. Available from: http://jac.oxfordjournals.org/content/49/1/ $185 \% 5 \mathrm{C}$

41. Nascimento MM, Lemos JA, Abranches J, Lin VK, Burne RA. Role of RelA of Streptococcus mutans in global control of gene expression. J Bacteriol. 2008;190:28-36.

42. Waller SB, Madrid IM, Ferraz V, Picoli T, Cleff MB, de Faria RO, et al. Cytotoxicity and anti-Sporothrix brasiliensis activity of the Origanum majorana Linn. Oil. Brazilian J. Microbiol. 2016;47:896-901.

43. Lei J, Yu J, Yu H, Liao Z. Composition, cytotoxicity and antimicrobial activity of essential oil from Dictamnus dasycarpus. Food Chem. 2008;107:1205-9.

44. Fallis A. Manual de toxicologia. J Chem Inf Model. 2013.
Ready to submit your research? Choose BMC and benefit from:

- fast, convenient online submission

- thorough peer review by experienced researchers in your field

- rapid publication on acceptance

- support for research data, including large and complex data types

- gold Open Access which fosters wider collaboration and increased citations

- maximum visibility for your research: over $100 \mathrm{M}$ website views per year

At $\mathrm{BMC}$, research is always in progress.

Learn more biomedcentral.com/submissions 